\section{No Reprieve for Stansted}

Modfrications have now been made to the plans to develop Stansted as London's third airport. But they bring little comfort to those who believe that the airport should not be built at all; the changes provide for a re-alignment of the runways which it is hoped will reduce the noise suffered by those who live near the airport. One result will be that the existing runway at Stansted will not be usable in the long term, and will go out of use in the late seventies. Because of this, and because the new plans need an extra 500 acres of land, the cost of the airport will rise by between $£ 8$ and $£ 10$ million. Costs are now put at $£ 45$ to $£ 50$ million in the immediate future, rising to $£ 80$ to $£ 90$ million by the end of the seventies.

The changes have shifted the direction of the runways rather more towards the north. They will no longer lie in the south-west/north-east direction which makes the best of weather conditions in the area, but the change is said to make only a trivial differenec to the problem of crosswinds. As a result of the changes, the Ministry of Housing and Local Government says that the number of people affected seriously by noise has been reduced from 28,600 to 10,500 , although the number of houses which fall within the perimeter of the airfield increases slightly under the new plan. It is not yet clear how many runways are to be built at Stansted; while the first one is being built, the existing one will be used. But when the second runway is completed the first will be phased out, and it is possible that another two will be built. Much will depend on the imponderables of air transport - very large aircraft, for example, could have the effect of reducing the need for four runways at Stansted. Vertical take-off transport aireraft are also a distinct possibility in the long term, although it is unreasonable to expect them to influence the first part of the Stansted plan.

Most opponents of the Stansted decision will conclude that this is the end of the struggle. But a group in the City of London has in the last week eome forward with an ambitious plan to build an airport at Foulness, in the Thames Estuary. The plan, for which no details have so far been released, originated with a firm of consulting engineers, Bernard L. Clark and Partners. Mr Clark, in collaboration with Sir John Howard, of the construction company John Howard, has put forward the idea. It would provide a combined airport and deep water docks on reclaimed land in the Thames Estuary. If the airport alone were developed, it would cost $£ 45$ to $£ 50$ million - with the docks, the total cost would be $£ 250$ million. So far, nobody is taking the plan very seriously - partly because Sir John Howard is away in Kenya on a business trip, and nobody else at his company is willing to comment -but also because of the great costs involved. Airports are not conspicuous money makers, and it is hard to see how the money could be raised. With the Government committed to Stansted, it is unlikely that it would provide either approval or financial support for the scheme.

\section{New Computer Company}

Computer Technology is a new British computer company whose first machinc will come off the produetion line in May. Modular 1, as the company's only model is called, will fill a niche only partly exploited by the large manufacturers and even then, its makers believe, will compete in both price and capability.

Based at Hemel Hempstead and at present employing thirty-five people, Computer Technology was founded two years ago by Mr Ian Barron, who had previously worked with Elliott-Automation. The company says that its machine can be made up from any desired number of compatible modules, each specific for such functions as processing, sorting and transmitting information. Modular 1 is a digital computer with integrated circuitry; its price depends on the number of modules required and can range from $£ 10,000$ to $£ 1$ million.

The company is financed by both British and international capital. The flexibility of the machine is claimed to be an assurance of a life of at least ten years without further research and development costs. It will be interesting to see how it fares among the Goliaths of the computer industry.

\section{How to Make Engineers}

A REPORT on the methods used to introduce secondary school students to engineering in Japan and Amcrica has recently been prepared for the Goldsmiths' Company by Mr G. C. Sneed. Mr Sneed's findings are of particular interest because, although in Britain university places in engineering may be too few, they are too many, it would seem, for British students. According to the 1966 report of the University Central Council for Admissions, there were 500 places left vacant in technology and 1,100 in pure science. The lack of interest among students may derive partly from the low social status of the engineer and partly from the lack of suitable instruction in schools.

An attempt to remedy this situation has been made by Mr Sneed of Ealing Grammar School, whose introductory engineering course, attended voluntarily by three-quarters of the science sixth form, has already been successful in encouraging highly able students to take degrees in engineering. Mr Sneed has now visited Japan and the United States to study the methods used there to encourage students towards the study of engineering at university.

In Japan, there is no lack of applicants for university engineering places. The value and national importance of engineers are publicly recognized. Japanese pupils in secondary schools are said also to be exposed for three hours a week to a subject called "industrial arts". The aim is to cover recent developments in Japanese science and technology, to impart some basic technical knowledge and to help children form a mental attitude towards modern life in which technology plays a major part.

Entrance to state universities in Japan is highly competitive, but it at least avoids the degree of specialization demanded by English universities. All students must pass examinations in mathematics, a scientific subject of choice, Japanese language and English language. For students attempting to enter a faculty of engineering, physics and chemistry are compulsory scientific subjects.

The training of science teachers is an important feature of Japanese education. There are now forty centres throughout Japan which are devoted to the training of science teachers. Mr Sneed reports that the 
centres are well equipped and staffed, and have met with undoubted success since their inception in 1960.

Mr Sneed says that the scale of Japanese education should not be underestimated. In 1966 there were 346 four-year universities, of which 111 were operated by the state. More than 70 per cent of Japanese children stay on at school until or past the age of 18 , and 11 per cent receive a university education. In England, 7.3 per cent of boys and 3.2 per cent of girls go to university; these figures, however, are not of course strictly comparable.

In the United States Mr Sneed says he has investigated the Engineering Concepts Curriculum Project (ECCP), a scheme which calls for the development of an introductory course in engineering and the training of teachers to conduct it. The aim is not specifically to attract students to a career in engineering but, like the industrial arts course in Japan, to provide an understanding of the technical background of modern life. There are signs that the popularity of engineering as a career in the United States is decreasing and, although it is too early yet to evaluate the course developed by the ECCP, its progress will be watched with interest.

\section{Education for Engineers}

Plans to bring the United States Commission on Engineering Education into the structure of the National Academy of Engineering were announced in Washington DC last week. The commission was founded by the National Science Foundation in 1962 to meet the needs for improving undergraduate education in engineering. It is supported by the NSF and by private means. Since 1962, the work has covered areas such as the educational aspects of computers, manpower requirements for engineers in specifie fields, the development of an Engineering Concepts Curriculum Project for high schools and the development of undergraduate engineering laboratories.

The reason for the proposed association is that the commission recognized a need to establish "a more substantial basis of operation than that provided by its independent status". According to Dr Eric A. Walker, president of the National Academy of Engineering, it is hoped that this relationship will encourage new ideas and new programmes as well as establishing co-operation with other organizations dealing with engineering education. Formal dissolution of the commission as a corporation will take place no later than March 1, 1969. Meanwhile, the commission will continue to administer existing programmes, and new projects will be handled by the Committee on Engineering Education within the academy.

\section{Some Steam Ahead}

THe award to a British company of a contract for a large turbine generator for Consolidated Edison in New York is a considerable coup at any time. To beat General Electric and Westinghouse, and the highly effective Swiss company Brown Boveri, adds savour to the triumph. But there must be some long faces in Associated Electrical Industries just the same. If the order had come only two months ago, it might have been decisive in turning away the bid with which
Mr Arnold Weinstock of the General Electric Company took over AEI. Naturally AEI is trying very hard to play down the issue, despite its jubilation at winning the order. Mr Weinstock, for his part, must be gratified that the turbine division of his new empire is already giving evidence of its competitiveness-it could mean one less problem for him, and keep alive hopes of maintaining the division through a difficult period. The Central Electricity Generating Board is now cutting back so hard on new orders-despite the recent cold spell, it still had substantial spare capacity- that there is little hope of selling generating capacity in Britain for the next two years or so. Export orders are therefore more than just an encouragement-they are a lifesaver.

The contract which AEI has won is for one turbine generator with auxiliary equipment, worth $£ 10$ million; but it is more than likely that an order for another similar unit will be forthcoming. Placing contracts in this way is a common practice in the United States, and AEI is confident of winning the option. The generator is of unprecedented size for a British company-1,100 MW from a single shaft, against the 660 MW units which the CEGB has reached. The unit will be run from a boiling light water reactor, and will be a relatively low pressure, low temperature unit, running at $1,800 \mathrm{rpm}$. These units are different from the ones the CEGB uses, which use a higher grade steam.

Because the steam from the reactor will be saturated with water, and partially decomposed into hydrogen and oxygen, there are particular corrosion and erosion problems on the turbine blades. The amount of erosion depends on the tip speed of the turbine blades, so it pays to keep this as low as possible. AEI has managed to do this by using a device developed by one of its engineers-the Baumann multi-exhaust. Although the other tenders for the Con Ed contract specified a blade size of 52 inches for the final set of blades, AEI says that its blades are much smaller. The generator will use a combination of cooling techniques. The stator will be water cooled, by a design which AEI itself developed. But, although there had been speculation that the rotor would also have to be water cooled on a unit this size, AEI have provided hydrogen cooling. This is not because it is technically impossible to cool the rotor with waterAEI is convinced that it knows how to do it-but merely because it might provide a weak link in the design. Cooling by hydrogen gas is well proved, so AEI has decided to use it.

The set will also be provided with a series of water separators, designed to remove as much water as possible from the steam. In the design of these, AEI will be calling on the experience gained in the contract for the turbines for the steam generating heavy water reactor at Winfrith Heath in Dorset. Although the SGHWR is very much smaller than the Con Ed contract, it shares some of the problems.

\section{The Lunar Society}

$$
\text { from D. G. Kin o-Hele }
$$

THE informal but influential meetings of the Lunar Society of Birmingham began about the year 1766, and its 200th anniversary was commemorated in 